Special issue of Social Movement Studies, 16.1, 2017

Resisting Austerity. Collective Action in Europe in the Wake of the Global Financial Crisis

Editors: Cristina Flesher Fominaya and Graeme Hayes

\title{
Regimes of Austerity
}

Social Movement Studies, 16.1, 2017, pp.21-35

Dr Graeme Hayes

School of Languages and Social Sciences

Aston University

Birmingham B4 7ET

United Kingdom

g.a.hayes@aston.ac.uk

\section{Biography}

Dr Graeme Hayes is Reader in Political Sociology at Aston University, and an Editor of Social Movement Studies. His work has been published in journals including Comparative Political Studies, Environmental Politics, European Journal of Political Research, Law and Policy, and Sociology. He is the author of two monographs and co-editor of three collections, most recently Occupy! A Global Movement. Hope, Tactics and Challenges (Routledge, 2014). 


\section{Regimes of Austerity}

\section{Abstract}

This article discusses the European wave of contention catalyzed by the financial market crash of $2008 / 9$ and the subsequent imposition of austerity measures by governments across the continent. It develops two central arguments. First, it argues that we need a clearer and more sharply differentiated understanding of the operation of austerity as a social and political phenomenon than can be accounted for by reading the crisis of austerity as a solely material set of grievances. Second, it dissociates austerity into a series of interconnected regimes, which are fiscal, ideological, political, and civic. In so doing, I show how the material aspects of austerity are intimately tied to the ideational, institutional, and spatial enclosures they create, enabling us to see more clearly how the practice of austerity is intimately tied to the progressive dismantling of collective democratic space. The transformative potential of anti-austerity mobilizations accordingly lies in their capacity to develop an alternative moral economy grounded in new forms of solidarity and sociability, whether in workplaces or in the civic squares.

\section{Keywords}

Austerity; strikes; occupations; pro-democracy movements; enclosure

Following the subprime lending crisis and subsequent financial market crash of $2008 / 9$, governments throughout Europe developed and implemented a series of debt reduction measures collectively known as austerity. Across the continent, social movement mobilization against these measures was often dramatic: in Greece, Rüdig and Karyotis (2013) report a 'staggering degree of political mobilization' for 2010, citing police figures recording in excess of 7000 demonstrations held in the country, and estimating that around $30 \%$ of Greeks participated in at least one formal protest that year; in Portugal, the Geração à Rasca ('Desperate Generation') protest of 12 March 2011 was the biggest demonstration to take place in the country since the 1974 'Carnation Revolution' and the transition to democracy, but even that protest was eclipsed by the 2 March 2013 demonstration organized by the Que se Lixe a Troika ('Fuck the Troika') platform (Accornero and Ramos Pinto 2015); in the UK, up to two million people went on strike in November 2011 in what the Trades Union 
Congress (TUC) called 'the biggest strike in a generation', in protest against public sector pension reforms; ${ }^{1}$ in November 2012, the European Trade Union Conference staged '14N', an unprecedented 'European Action Day' of transnational, cross-sectoral, and simultaneous strikes in six countries, supported by union rallies and demonstrations in a further seventeen countries (Dufresne 2015, pp.151-3).

Mass protests were not restricted to southern and western Europe. Economic crisis, structural adjustment and public sector reform generated remarkable mobilizations in the Balkans and CentralEastern Europe: in Slovenia, a country of two million people, 150,000 workers in the public and private sectors participated in a collective walk out against wage cuts in 2008 , and 100,000 public sector workers organized a general strike in February 2013 (Musić 2013); Varga (2015) reports that, variously, in the Czech Republic, 'Stop the Government!' protests that started in 2010 culminated in April 2012 with a demonstration mobilizing 120,000 people, the largest since 1989; in Poland, the largest trade union confederations (including Solidarity) organized a general strike in Silesia, with 100,000 steel, mining, energy, and transport workers taking part; and in Romania, unions mobilized 750,000 public sector workers in a general strike in October 2009, 50,000 supporters for a demonstration in the centre of Bucharest in May 2010 (here again, the largest since 1989), and the following month 700,000 workers participated in a further one-day public sector strike. Attempts by the Romanian government to privatize the health care system sparked mass protests in January 2012, forcing the government to abandon its plans. In Bulgaria, too, public contention was widespread, as protests against a rise in energy prices in 2012-13 forced the resignation of the government, and mutated into a wider mobilization against corruption and the lack of democratic representativity (O'Brien 2016).

For many observers, these and other protests were 'diverse instantiations of an international cycle of contention fighting against social and economic inequality' (Tejerina et al 2013, p.381), part of a larger 'global wave of contention' (Flesher Fominaya 2014a). From the 'Arab Spring' to Occupy, Iceland to Brazil, multiple 'movements of the crisis' (Della Porta and Mattoni 2014) staged walkouts, demonstrations, and occupations against the prevalent national (and sometimes transnational) economic and political orders. Della Porta, in her extensive study of anti-austerity movements, argues that these protests particularly mobilized those directly affected by the crisis of neoliberalism, as students, precarious workers, industrial workers, and public employees formed an emergent coalition, pointing to the importance of a new social cleavage, that of the precariat (2015, pp.16-17). This new class is excluded economically, and also politically: the crisis is of political responsibility (in Habermasian terms, a systemic crisis of legitimacy). 
Other writers have drawn a more direct line between the economic impacts of the recession and the pattern of protest following it. Indeed, a number of recent studies have argued for a positive association between the objective conditions of economic crisis and the incidence of protest behaviour across Europe from 2009-10, such that citizens in states experiencing rapid growth in unemployment levels were more likely to participate in protest, and to do so regardless of their own specific individual circumstances (Kern, Marien and Hooghe 2015, Quaranta 2016). Some scholars have seen in these protests evidence of a new 'materialist turn' both in public protest in Europe and the organization of academic enquiry into social movement mobilization (see, for example, Rüdig and Karyotis 2013, Bailey 2014). For Peterson, Wahlström and Wennerhag, in a context marked by first the emergence of the global justice movement and subsequently the wave of anti-austerity protests after 2010, 'we can no longer neglect the materialist focus of contemporary protest' $(2015$, p.294).

In this article, I aim to provide further conceptual clarity to the operation of austerity and its relationship to the collective social mobilizations opposing it. I set out a broad overview of the (by now) wealth of writing on European anti-austerity mobilizations, in order to argue that if we are to develop a sophisticated understanding of the character of protest mobilization in Europe following the financial crisis, we first need a clearer and more sharply differentiated understanding of the operation of austerity as a social and political phenomenon than can be accounted for by reading the crisis of austerity as a solely material set of grievances. In so doing, I aim to draw our attention away from the temptation to reify austerity, to consider it as qualitatively separate from a concurrent crisis of social and democratic participation. Rather, I seek to underscore how these impacts and policies are intimately tied to an ongoing process of democratic enclosure, which operates at the ideational, spatial, and political system levels. I therefore argue that rather than casting anti-austerity mobilizations as either motivated by primarily materialist (or indeed democratic) concerns, we should see these concerns as mutually constitutive, as co-productive.

Central to my reading is the internal moral economy, or ethical schema, of austerity itself. Austerity is not simply a fiscal debt reduction strategy: rather, it is a social disciplinary process imposed through debt transfer (from private to public, affluent to poor), and conducted against the most socially and economically vulnerable sections of the population in disproportionate and specificallytargeted ways. In order to target these populations, the deserving are separated from the undeserving, and subjected to an interventionist apparatus of surveillance and coercion. To be sure, these elements are already structurally central to neo-liberalism: indeed, Lazzarato (2012) places the creation of the indebted subject, homo debitor, at the heart of the disciplinary apparatus of neo- 
liberalism. As such, austerity is a continuation, and - post-crisis - intensification of established neoliberal dynamics. Yet, precisely because neo-liberalism generated the financial crisis, its operation also requires a process of re-allocating responsibility for repayment, from the logics and practices of financial market capitalism to a fictional collective 'we', to unionized public sector workers, and to welfare claimants in particular (see for example O'Flynn, Monaghan and Power 2014).

Austerity therefore is 'not simply a re-run of traditional moralizing about welfare claimants, but rather a use of welfare to refashion economic and social relations on a grander scale', as Morris puts it $(2016$, p.101). In other words, austerity is a process of social restructuring whose legitimizing framework is an explicitly stigmatizing and exclusionary one. This has numerous consequences for the operation of austerity, but also for the way we approach collective mobilization against it, and the way we understand the production and role of material impacts within it. Key here is the reduction of democratic space. Cairns et al (2016) stress that, in order for the process of social debt transfer to succeed, it must necessarily be made visible: 'a population needs to be seen, heard and felt to be suffering in order to assuage the fears of external creditors and assure any potential new investors and the markets that alleged spendthrift tendencies have now been resolutely curbed' (pp.9-10). A consequence of this necessary visibility of austerity's own explicitly exclusionary tendencies is that the generation of counter-mobilizations also becomes fundamental to its operation. Protest signals the effective functioning of the disciplinary process to institutions and creditors and publics; for Cairns et al, 'the public presence of political unrest is a sign that austerity measures are functioning correctly rather than an indication of policy failure' $(2016$, p.10).

As a set of fiscal processes therefore, austerity is intimately and inescapably tied to a logic of democratic enclosure. This is because it is dependent upon the prior creation of an ideational and institutional environment whose representational operation is exclusionary, and because its own functional success depends upon the further material and symbolic disqualification of specific publics. Yet this presents something of a bind for the conceptualization of anti-austerity mobilizations, for two reasons. First, attention to social mobilizations risks neglecting the extent to which these mobilizations are integrated into the operation of austerity itself, or, conversely, to the ways in which they might be not just politically oppositional, but potentially transformative. Second, the material contours of economic grievance generated by the crisis are far from uniform: even at the most general level of analysis, ideational and structural differences in European economies are germane to the levels and character of financial distress experienced by different states and groups of states. As a consequence, analysis risks being caught between two levels of enquiry. On the one hand, an attention to the granularity of context, a specificity which focuses on causal detail but does so at the 
expense of a general explanatory value of social action; and on the other, an attention to the systemic properties of grievance and counter-mobilization, an approach which risks disembodied decontextualization. Focus on either level risks assuming a false (if superficially attractive) causality between austerity stimulus and collective response.

In what follows, in order to draw out the relationship between fiscal policy and the reduction of democratic space, I disassociate austerity into four separate but interconnected regimes: fiscal, ideological, political, and civic. Here, the term regime denotes the sense in which the political translation of the financial crisis across Europe can be identified by (i) recurrent, inter-related, and dominant sets of institutionalized practices of social and economic regulation, underpinned by broadly shared norms over the boundaries and legitimacy of neo-liberal governance; and (ii) shared assumptions over the appropriate sets of policy response to the systemic crisis of deregulated market capitalism, not just in economic terms but in the wider social and political mediation between states and citizens. The notion of regimes, therefore, enables the identification of recurrent patterns and practices, and of the norms that underpin these practices, but without ascribing a uniform, systemic character to them.

I argue that the dissociation of the concept of austerity into interlocking regimes is helpful in that it enables a fuller understanding of the socio-economic impacts of the economic crisis. Equally, however, it enables us to apprehend their symbolic translation within the multiple forms and claims of anti-austerity activisms, from industrial action and labour union demonstrations to the formation of radical left parties and the collective occupation of public space, the critique of representative democracy, and the emergence of the 'citizen' as a mobilizing identity. By outlining both the operation of austerity and the social movement responses to it, I am drawing attention to how austerity affects the conditions of social mobilization in multiple ways, but also how the framework of austerity is understood and processed by social movement actors. In this sense, my starting position is that it is not tenable to read off the incidence of anti-austerity mobilizations from either the prior structuring of local contexts, or from the form and extent of the impacts of the economic crisis and the set of austerity measures allegedly designed to remediate them. Rather, the potential of social movement action is to identify and reveal the processes of exclusion and enclosure that austerity produces, and enable the development of alternative imaginaries of action and association. I argue accordingly that our attention as scholars should be drawn to movement practices, to the way that movements negotiate the operation of austerity in action and discourse, and to the politically transformative possibilities that social movements articulate. 
This paper proceeds in four sections, delineating in turn the fiscal, ideological, political, and civic regimes of austerity, and the various collective movement responses to them across Europe.

\section{Fiscal Austerity}

Fiscal austerity is chiefly composed of structural reforms of state pension provision and the labour and housing markets, allied to reductions in welfare budgets and the privatization or marketization of public services, as governments across Europe reacted to the sovereign debt crisis by transforming private debt into public debt. Kickert and collaborators identify three successive phases of the crisis: first, a banking crisis originating in the United States in 2007 which, following the collapse of Lehman brothers in September 2008, triggered a series of bailout measures taken by governments to support the banking and financial services system; second, an economic crisis as governments reacted to dramatic falls in GDP and employment by implementing economic stimulus packages; and, third, a fiscal crisis, characterised by measures taken to consolidate budgets and recover the incurred debt (Kickert 2012, Kickert, Randma-Liiv and Savi 2013, p.6).

It is in the second of these phases that the initial actions within the cycle of contention were launched. In Iceland, from October 2008, demonstrators started to gather every Saturday in front of the parliament building in Reykjavik's Austurvöllur Square; in January 2009, the government eventually resigned, following six days of intense and unprecedented mass protests (Bernburg 2016). In the UK, Bailey identifies a wave of contentious actions starting in the final quarter of 2008, characterised by a causal relationship between the increased incidence of protest and the onset of the economic crisis (rather than the introduction of fiscal retrenchment measures), the prevalence of confrontational forms of action (including wildcat strikes and factory occupations) at the start of the wave, and by the participation of a 'a broader range of actors than that witnessed in earlier periods' (2014, p.81), including workers but also anti-cuts campaigners and 'radical activists'. In a small number of cases - at Simclar (Ayrshire), Calcast (Derry), Prisme (Dundee), Visteon (Belfast and Enfield), and Vestas (Isle of Wight) - manufacturing workers occupied their premises in the face of suddenly announced redundancies (Gall 2011). In France, confrontational action was similarly prevalent in the immediate months of the crisis, as between spring 2009 and summer 2010, workers threatened with factory closures or significant job losses undertook a series of 'bossnappings', and did so on a much more widespread scale than the factory occupations in the UK: in multiple locations, workers forcibly detained company CEOs, HR directors, and plant managers for periods of up to 48 hours in order (often successfully) to force companies to improve redundancy terms (Hayes 2012). 
In both Spain and Italy, occupational practices predominantly centred on domestic housing. In both countries, the housing market is characterized by a high degree of ownership (around 85\% for Spain, $69 \%$ for Italy), low rates of social renting, and where the family (rather than state welfare) plays an important cultural role as a social safety net (Cano Fuentes et al 2013, Baldini and Poggio 2014). In both countries, economic crisis and unemployment produced serious secondary crises in access to housing, with evictions and the demand for social housing increasing significantly. In Italy, networks such as Abitare nella crisi responded through mobilizing against evictions and in support of housing rights (Mazzamauro 2014). Further, though there is a long tradition in Italy of occupation and selfmanagement, and of political squatting, housing occupations also increased significantly in the wake of the crash: as Bosi and Zamponi put it, at no point in the previous three decades had such actions 'reached the scale, level of coordination, or sheer centrality in the public sphere as they have now in the context of economic crisis' (2015, p.375).

In Spain, housing arguably became the central point of contention in the effects of the crisis and subsequent social responses to it, as banks ordered nearly 400,000 evictions between 2008 and 2014 . In response, the PAH - Platform for People Affected by Mortgages - was created in 2009, not only to lobby government for the creation of social housing stock or to change the laws concerning foreclosure, but to physically oppose and block evictions, enable evicted families to occupy newly constructed apartment buildings (usually belonging to banks), and carry out actions known as escraches, where activists directly target those they consider responsible, holding demonstrations outside the homes of politicians or the headquarters of banks (Romanos 2014). Escraches are an 'act of moral repudiation' (Flesher Fominaya 2015a, p.473). To an extent, they therefore resemble French bossnappings: beyond their instrumental aims, they aim not just to expose political and corporate powerholders and demonstrate their causal responsibility for decisions which destroy lives and livelihoods, but to make these targeted individuals feel physically uncomfortable through their enforced participation in a counter-hegemonic public theatre.

This specifically innovative confrontational character of action is not necessarily reproduced across the continent. But what is key is that this initial phase of social contestation is driven by the material consequences of the economic crisis for individual citizens (loss of employment, security, housing). It is also primarily characterized by industrial labour conflict, in both the public and the private sector, and predominantly involves strikes and trade union-sponsored demonstrations. In the five years 2010-2014, 48 general strikes were held in western Europe, with peaks of fourteen and twelve in 2010 and 2012. The vast majority of these general strikes took place in countries which combined severe economic crisis with a culture of political strikes: 23 were held in Greece, ten in Italy, six in 
Portugal, two in Spain, as well as five in France, and two in Belgium; by way of comparison, there had been 38 general strikes, or ten fewer, in the ten years 2000-2009, twice as long (ETUI 2016; see also Nowak and Gallas 2014). Even in Ireland, where there is little tradition of militant trade unionism and where the dominant union culture is pragmatic and accommodatory, strike volume (the number of days not worked because of industrial action) nonetheless rose to four times the EU average in 2009 (Geary 2016). On 24 November that year, a quarter of a million public sector workers staged the country's largest ever one-day strike, protesting against the Fianna Fail/Green coalition government's plan to cut public sector pay and service in order to plug the deficit caused by the state bailout of Irish banks.

It is not until 2010-11 that Kickert's third crisis phase, that of fiscal retrenchment, that we see collective action against fiscal austerity per se. The extent of the fiscal adjustments enacted by states varied: in Spain, Portugal, Greece, Cyprus, Ireland and Italy it was comparatively large. Retrenchment also took different forms in different states. Yet as the average public deficit in the EU almost doubled between 2007 and 2008, reaching 6.4\% of GDP in 2009 and twelve states entered the EU's Excessive Deficit Procedure between 2008 and 2010, ${ }^{2}$ most European countries launched multi-year deficit reduction programmes. In cases where the 'Troika' of the European Commission, European Central Bank, and International Monetary Fund agreed to very significant emergency bailouts (a $€ 110$ bn loan package to Greece in May 2010, a €67.5 billion package to Ireland in November 2010, and a €78bn package to Portugal in May 2011), receiving states were required to implement draconian structural reforms. Even where conditions were not imposed by the Troika, peripheral EU states adopted a combination of common approaches to the economic crisis, notably targeting reductions in public expenditure on health care, pensions, welfare systems (unemployment and social security), local authority budgets, public sector pay and employment, and infrastructure (Kickert, Randma-Liiv and Savi 2013, Alesina et al 2015).

Typically across the continent as states move to fiscal retrenchment, the character of social contestation changes, mobilizing a wider range of citizens and collective actors, with demands which evolve beyond the primarily materialist demands of organized labour. Notably, this takes place from spring 2011 onwards. Three factors explain this. First, the European social climate, particularly in Mediterranean states, is heavily influenced by the series of regime-challenging mobilizations across North Africa, and chiefly by the mass occupation of Tahrir Square in Cairo by pro-democracy movements (Baumgarten 2013, Tejerina et al 2013, Roos and Oikonomakis 2015). Second, a wave of elections, particularly general elections, in southern European states variously: highlights the absence of an alternative politics amongst institutionalized parties in the face of the crisis; produces 
new governments committed to the implementation of fiscal retrenchment policies which are more severe than those proposed by the now defeated incumbent governing parties; and, in the case of Greece, brings to light the astonishing scale of economic mismanagement and public deception practiced by the previous government (Bosco and Verney 2012, Tsatsanis, Freire and Tsirbas 2014). Third, fiscal retrenchment policies are implemented, revealing the effective transfer of national debt from transnational private capital to localized public services and welfare recipients, and producing specific sites and sets of collective and individual impacts and resistances.

Together, these impacts and resistances point beyond the economic crisis to the political, cultural, and institutional crises of European social democracy and, at a systemic level, of European representative democracy, making manifest the ideological, political, and civic regimes of austerity which underpin the operation of fiscal austerity, as I will discuss below.

\section{Ideological Austerity}

In ideological terms, the banking and economic crises brought into sharp focus the long-running crisis of social democracy in Europe, and the failure of social democratic parties to offer a coherent alternative to neo-liberal politics, within or outwith the eurozone. Ideological austerity constitutes, in Bosco and Verney's phrase (2012), 'democracy without choices': an overarching regime spanning the policy choices offered by institutionalized parties of right and left, in which the electorate can change the composition of governments, but not their underlying policy orientations. Ideological austerity is therefore defined by the lack of fundamental ideational and programmatic divergence between the institutionalized parties of government, particularly with respect to macro-economic management.

In the systemic terms of representative democracy, the electoral consequences of the implementation of fiscal austerity policies produced a negative 'incumbency effect', as governing parties across Europe were held responsible by their electorates both for the crisis and for the subsequent recession. In his analysis of the first parliamentary elections in 30 European countries following the Lehman Brothers collapse, Kriesi (2012) finds that incumbent parties were severely punished for the consequences of the crisis, such that the greater the budgetary deficit in the year preceding the elections, the greater the punishment of the government. Notably, Fianna Fail collapsed in the spring 2011 Irish general election (the first to be held post-crisis); Gordon Brown's New Labour government was defeated in the UK in May 2010, to be replaced by a Conservative Liberal Democrat coalition, itself wedded to a highly punitive fiscal austerity programme. 
However, the punishment of incumbents was particularly widespread across southern Europe in what Bosco and Verney (2012) call an 'electoral epidemic'. In Greece, though the ruling PASOK party appeared to have done well in the 2010 local and regional elections, these elections also revealed significant weaknesses in the party's support base, leading to the eventual fall of the Papandreou government in May-June 2012 (see Karyotis and Rüdig 2015, pp.18-19); in Portugal, Prime Minister José Sócrates lost a confidence vote in parliament in March 2011, and the governing socialist party lost 23 seats in the subsequent June 2011 general election, with its share of the national vote falling below 30\% for the first time since 1991; and in Spain, after seven years in office, the PSOE recorded at the November 2011 general election its worst election results since the transition to democracy, with Prime minister José Luis Rodríguez Zapatero's party losing over 4.3 million votes since the March 2008 election (see Martín and Urquizu-Sancho 2012).

What is perhaps most striking about these defeats for incumbents is that - in Portugal, Spain, Greece, and the UK - they concerned centre-left parties. In a series of elections held from spring 2010 onwards, citizens across Europe punished centre-left parties for proposing a series of fiscal retrenchment policies, such as the marketization or privatization of public utilities and services. Yet, at the ballot box, they were only able to vote into government right-wing parties committed to pursuing these same policies, but more rapidly, more severely, and even less equitably. ${ }^{3}$

For the centre-left, the elections of 2011-12 revealed a structural rather than purely conjunctural crisis. As Keating and McCrone (2013) underline, the key tenets that have historically underpinned European social democracy, broadly defined - universalism, market regulation, social solidarity, collective bargaining, the extension of democratic participation, a cultural liberalism organized around the promotion of minority rights - came under increasing stress in the final quarter of the twentieth century, assailed by economic globalization, the decline of trade unionism, the emergence of new social divisions between public and private sectors, mass migration, and especially, European integration. Social democratic parties themselves played a central role in the creation of a European integration project whose institutional design, and especially monetary governance architecture, privileges markets and economic inequality over social welfare (Stiglitz 2016).

Though there is evidence to suggest that, counter to received opinion, 'niche' parties (ie radical left, radical right, Green, and single issue parties) do not in fact prosper in times of austerity (Grittersová et al 2016), the role of social democratic parties in setting the structural conditions of economic crisis, together with their failure to offer alternatives to fiscal austerity, also opened up an ideological space for party system realignment. Insurgent parties on the left (and sometimes on the right) claimed 
ideological space to promise the alternatives to fiscal retrenchment and budget discipline that exhausted parties of the centre-left could not (and that parties of the centre right would not) articulate. Thus new formations emerged to offer a radical left, oppositional politics, challenging the fundaments of fiscal austerity: in Greece, Syriza gained 16.8\% of the vote in the May 2012 parliamentary elections and $26.9 \%$ six weeks later, becoming the second largest party in the Greek parliament, and winning 149 of the 300 parliamentary seats in the January 2015 general elections; in Spain, Podemos, formed in March 2014, gained just under $8 \%$ of the national vote (and five MEPs) at the European Parliament elections two months later, and 21\% of the vote at the December 2015 general election, becoming the third largest party in the Spanish parliament; and, in the UK, Jeremy Corbyn was elected leader of the Labour party in summer 2015, promising an anti-austerity programme and a new kind of movement politics.

\section{Political Austerity}

In turn, the implementation of fiscal austerity packages across Europe revealed not just the operation of a regime of ideological austerity within party systems, but also, more widely, of political austerity: in other words, not simply democracy without programmatic choices, but democracy without social representation. The democratic deficit denounced by anti-austerity mobilizations concerned not simply the orientations of institutionalized parties and the lack of ideational alternatives to fiscal austerity that they articulate. Rather, the critique of political austerity is located in the operation of political institutions themselves, the systems of representative democracy that underpin them, and the network of relations with other institutions that constrain them. In particular, political austerity is characterized both by the suspension of 'normal' democratic procedures as national governments agreed to reforms imposed by international and supranational economic and governmental institutions (the Troika of IMF, ECB, European Commission, ratings agencies, financial markets), themselves enjoying limited democratic legitimacy (at most); and by the longer-run dynamics of European representative democracies, even in their 'normal' configuration, which have increasingly privileged corporate influence over public participation in decision-making.

Crouch, in fact, places the crisis of social democratic parties, with mass memberships and historic commitments to the extension of both the welfare state and democratic engagement, at the centre of a wider crisis of the functioning of representative democracy, in which the mass of citizens play an increasingly quiescent and passive part. Under the conditions of what he terms 'post-democracy', power is instead ceded to elites and experts representing business interests, leaving little space for the development of a politics capable of achieving a significant redistribution of either power or 
wealth (2004, p.4). Mair, likewise, places changing patterns in party representation - in his analysis, the decline of electoral engagement and voter identification with parties amongst western European publics in the 1990s - as symptomatic of a self-reinforcing division between political elites and mass publics, as disengagement fuels privatized decision-making, in turn fuelling further disengagement. The consequence is a sharpening separation between popular and constitutional democracy, such that 'the citizenry are becoming effectively non-sovereign', as we witness the emergence of 'a notion of democracy that is being steadily stripped of its popular component-democracy without a demos' (Mair 2006, p.25).

This element of critique is fundamental to anti-austerity mobilizations, for two reasons. First, the material dimensions of the crisis were perceived by numerous movements as integral to the cession of popular political sovereignty to the troika, the banks, and to global financial markets; solutions thus lay at the level of the political system, through the development of participatory (and sometimes direct) democratic alternatives, and the rejection of neo-liberal growth politics. Second, because - in the physical spaces of the squares and assemblies (Pino 2013), the virtual spaces of internet platforms (Gerbaudo 2012, Monterde et al 2015), and the experimental spaces of social centres (Yates 2015) - anti-austerity mobilizations placed the development of new forms of organization and decision-making at the heart of their attempts to reclaim democracy through the creation of a public deliberative sphere.

To a certain extent, systemic critique is present in union-led anti-austerity mobilizations. The incidence of general strikes across southern Europe, as Nowak and Gallas note, is all the more remarkable for their occurrence in local contexts characterized by the long-term decline of sectoral strikes, with unions increasingly unable to organize mass industrial action in the face of neo-liberal economic restructuring. These general strikes are, above all, political strikes, in the sense that they are directed against government plans to restrict rights and cut social expenditure, and more generally, the undemocratic character of political crisis-management in Europe (2014, p.312). The increase in general strikes is therefore a consequence of the translation of the site of struggle from the material-economic to the political-institutional. Yet even where they are political, these strikes remain primarily defensive, with few transformative demands at the systemic level. Equally, conflictual workplace actions have been predominantly defensive, with objectives that are rarely as radical as their form (Hyman 2015, p.100). Thus the primary goals of occupations have been attempts to keep production sites open, or negotiate better redundancy terms (as, for example, in France; Hayes 2012). Moreover, despite 14N transnational strike action of November 2012 organized by ETUC, unions have been noticeably unable to mobilize around transnational solidarities. For 
Hyman, indeed, there is 'an evident contradiction between the global nature of the economic crisis on the one hand, and trade union action that is essentially national or indeed sub-national in character' (2015, p.103).

In contrast, the emergence of 'indignados' social movements across southern Europe in spring 2011, occupying public spaces in the centres of major cities and the neighbourhoods beyond, allied a critique of fiscal austerity to one of the systemic functioning of representative democracy. In Madrid's Plaza del Sol, Barcelona's Plaça de Catalunya, Lisbon's Praça do Rossio, and Athens' Plateia Syntagma, as well as in many other districts, towns and cities across southern Europe (particularly in Spain), these movements lay claim to public space through the establishment of acampada (encampments) and social centres. In so doing, they routinely and commonly opposed 'the dictatorship of the markets', whilst practicing and advocating a transformative politics of participatory decision-making and creatively imagining multiple emergent forms of social solidarity such as, for example, the explosion in community currencies in Spain (Hughes 2015), or the further development and proliferation of solidarity purchase groups in Italy (Forno, Grasseni and Signori 2015, Guidi and Andretta 2015). Feeding off each other, these movements were in turn important to the proliferation of Occupy movements across Europe and North America in the Autumn of 2011 (Castañeda 2012, Romanos 2016), as well as to subsequent protests, such as Gezi Park in Istanbul in spring 2013, and the Place de la République in Paris, in the Nuit debout protests of spring 2016 (Pleyers 2016).

What connects these protests is both a form of action, the horizontal public encampment, and a set of demands and practices which challenge the disciplinary disempowerment of the citizen as a condition of the imposition of fiscal austerity. The central call in these occupations was for 'Real Democracy Now', from the slogan of the Spanish Movimiento 15-M, 'Democracia real iYA! No somos mercancía en manos de políticos y banqueros' ('Real Democracy Now! We are not merchandise in the hands of politicians and bankers') to the Portuguese Verdadeira Democracia Já and the demand of the Greek indignados, or Aganaktismenoi, for Amesi Dimokratia Tora! (Direct Democracy Now!). Discussing the Spanish case, Flesher Fominaya highlights the deep interconnections between the rejection of fiscal austerity and the development of radical democratic positions, as the 15-M 'combines pre-figurative practices of radical democracy within social movement spaces with a highly organized attack on the illegitimacy of representative democratic institutions' (2015b, p.154). These mobilizations are not simply a resistance to the material aspects of austerity, therefore, but a collective reclamation of the public. As such, they go beyond defensive claims-making to articulate a transformative participatory politics. Indeed, as Asara points out, not only did 15-M not focus on 
economic growth-oriented solutions to fiscal austerity, but placed the critique of both growth and 'economism' at the centre of its analysis: Indignados mobilizations for social rights across education, health, and housing 'went hand in hand with the claims for a different economic model not based on economic growth and ever increasing consumption' (2016, forthcoming).

\section{Civic Austerity}

Conflict over the right to urban space consequently lies at the heart of the politics of austerity. Civic austerity is austerity's fourth regime of democratic exclusion and enclosure, a result of the ongoing neo-liberal privatization of public space, and the evacuation of resistant social representation from these spaces. As Meegan et al (2014, p.141) emphasize, austerity is an especially urbanized process, as cities are specifically targeted for policies of fiscal retrenchment given their disproportionate reliance on the public sector (both through the provision of services and the employment of public sector workers), and the predominantly urban location of populations targeted for reform, such as welfare, social housing, pensions, and so on. Austerity targets the city in both its roll-back and rollout variants (Peck and Tickell 2002): roll-back, through the accelerated dismantling and discrediting of Keynesian welfarism and social-collectivist institutions; roll-out, through the further expansion of market logics into the public realm, including the privatization and commodification of formerly civic, collective, and public spaces. For Tonkiss, cities, 'if they were key sites for the production of crisis, have since become key targets for a punitive politics of austerity' (2013, p.312).

For cities in western and southern Europe, post-2008 fiscal austerity measures are enacted in the context of decades of neoliberal restructuring, which have already transformed the dynamics of urban space. Hodkinson (2012) and Mayer (2013) identify the central model of the neoliberal city to be that of the 'enclosure', as the twin processes of housing market deregulation and gentrification on the one hand, and dispossession, displacement, and securitization on the other, create highly differentiated urban geographies. These geographies of neoliberal governmentality are characterised by enclaves of wealth situated within, as Mayer puts it, 'new regions of deprivation, dispossession and marginalization'. Post-2008, regimes of fiscal austerity implemented by central and local governments across Europe and North America have served to intensify rather than alleviate these dynamics of privatization, securitization, and zoning.

Collective material resistances to the urban politics of fiscal austerity have accordingly been typified by struggles (i) over the corporate ownership of domestic private space (most notably, struggles against evictions in Spain and the mobilization of PAH (outlined above), or the 'public repossession' 
by Occupy London of empty bank offices in late 2011); (ii) against the foreclosure of civic spaces (such as, in the UK, movements to defend libraries and leisure centres, perhaps most obviously the 'squatting' of Barnet public library in north London in September 2012 to keep it open to the public); 4 (iii) against the marketization of public services (such as the marea blanca of health professionals occupying hospitals in Spain, or the mass protests against health care reform in Romania); and (iv) over the ownership of public space, as typified by the 'movements of the squares' in southern Europe, and the wave of Occupy mobilizations in northern and Western Europe (and beyond).

These movements, through mobilization and public encampment, develop resistances to austerity through what Sbicca and Perdue (2014) term 'spatial citizenship', the reclamation of public space as the privileged locus of active democratic engagement. On the one hand, the civic regime of austerity generates new sites of what Lefebvre calls 'spatial contradictions' (1991, p.365), as social and spatial orderings are mutually constitutive processes; collective social conflicts are inescapably expressed in and themselves reconfigure existing geographies of capitalism. For Pickerill and Krinsky (2012, p.280), a central feature of the Occupy movement was its capacity to 'forc[e] society to recognise that capitalist accumulation happens in certain places, and that these places can be named, located and objected to'. On the other hand, precisely because the tactic of occupation is able to identify and reveal these spatial contradictions, it is also a potentially foundational move in the development of a new politics of the civic.

In turn, state responses to these public struggles have been characterized by a wave of measures seeking to circumscribe the expression of social dissent. For example, Amnesty International (2013, p.246) reports the 'excessive use of force by police' while dispersing crowds during Indignados protests in Spain, and the excessive use of force, the use of arbitrary detention, the obstruction of medical assistance to injured demonstrators, and violence against photographers and journalists - as well as demonstrators - during anti-austerity protests in Greece, particularly in June 2011. The excessive use of force by the Greek police is highlighted by Amnesty as 'repeated' and 'routine', includes the use of chemical sprays against peaceful or largely peaceful demonstrators and of stun grenades in ways violating international standards (Amnesty International 2012).

More widely, in the face of both union-led protests and indignados-type movements, public authorities across Europe have used a variety of methods - including introducing general and specific legislation, implementing exclusionary spatial zoning, developing new policing and surveillance technologies (such as the police 'kettling' of demonstrators in the UK, a practice denounced by the UN Human Rights Council $(2013$, p.8) as having a 'powerful chilling effect on the exercise of freedom 
of peaceful assembly'), and reducing access to legal redress - to constrain fundamental civic and political rights. A report commissioned by the European Parliament's Committee on Civil Liberties, Justice and Home Affairs identified a 'surge in State repression policies', from 'interferences' in the organization of protests to significant new constraints on the freedom of assembly and the exercise of civil liberties, in the wake of anti-austerity protests $(2015$, p.120).

The most egregious forms of this restriction of 'negative rights' amongst the countries that have witnessed significant anti-austerity mobilizations are measures introduced in Spain and the UK. In Spain, Mariano Rajoy's right-wing government passed the Ley Orgánica de Protección de la Seguridad Ciudadana, or Citizen Security Law, in March 2015, with its dispositions coming into force from 1 July the same year. Popularly known as the Ley mordaza, or 'gag law', these dispositions include the criminalization of and introduction of severe penalties for various forms of public protest; sanctions include fines of up to $€ 30,000$ for protesting in front of the Spanish parliament building, stopping a housing eviction, taking photographs of the police without permission, participating in a sit-in or a human chain (which acts are requalified by the law as the criminal offence of 'passive resistance to authority'). Fines of up to $€ 600,000$ can be imposed for the offence of participating in an unauthorized protest near 'key infrastructure'; what constitutes key infrastructure is as yet undefined (Flesher Fominaya 2014b). In the words of Maina Kiai, UN special rapporteur on the rights to freedom of peaceful assembly, the reform 'unnecessarily and disproportionately restricts basic freedoms such as the collective exercise of the right to freedom of opinion' $;{ }^{5}$ for Rights International Spain, its purpose is simply to 'prevent the use of public space for political participation' (Vicente and Goicoechea 2015).

In the UK, following its victory in the 2015 general election, David Cameron's Conservative government introduced the Trade Union Act 2016. In it, the government did not seek to formally ban strikes - currently at a historic low in the UK - but rather impose increased conditionality upon the ability of unions to successfully secure a mandate from their members. This conditionality takes the form of ballot thresholds: where, previously, a simple majority of votes was required for a union to take strike or industrial action following a ballot, the Act now also requires a $50 \%$ turnout of all eligible members. Further, in what are considered 'important public services' - not just health and fire and nuclear, and so on, but also the education and transport sectors - a double threshold now applies: in these services, in order to take industrial action, unions henceforth also have to secure a 'yes' vote of at least $40 \%$ of all eligible members. In other words, if the legal minimum of $50 \%$ of members participate in the ballot, at least $80 \%$ of them will have to vote in favour in order for a union to be able to take action. Practically therefore, the net effect of these (and a series of other) 
changes is that industrial action in the public sector in particular is likely to become very difficult, if not impossible, to organize. The Act thus effectively forces unions to manage their own inability to exercise their (still legally existent) right to take industrial action (Gall 2016); for the TUC, it 'marks a high point of interference in labour rights to organise in the UK which hits to the heart of the right to freedom of association'.6

\section{Conclusions: Austerities, Practices, Resistances}

In this article, I have sought to develop two central lines of thought about the European social mobilizations against austerity. First, I have sought to situate recent analyses that characterize antiausterity mobilizations as evidence of a 'material turn', particularly on the basis of an increase in industrial conflict in Europe since 2008. Support for or rejection of this thesis is doubtless dependent on a series of factors that have less to do with the 'objective' nature of economic impacts and more to do with the contrasting epistemologies and ontologies of different disciplinary positions. Thus critical analysis that is quantitative, draws on mobilizations prior to or beginning in 2008 , and takes Europe as its scale, is better able to identify a 'material turn' in the mass union led mobilizations which responded to the economic consequences of the market crash (and which, in many places, was less 'cyclical' than extremely short-lived). Equally, detailed qualitative work, whether ethnographic or interview based, which focuses on 2011 and its echoes and whose scale is that of the specific and variegated urban sites of dissent to fiscal austerity, is better able to highlight the movements of the squares, their networks, identities, practices, and genealogies, and thus identify what Flesher Fominaya (2015b) calls a 'democratic turn', grounded in the materiality of historicized space (and which, in many places across the continent, was either highly contained or did not occur at all).

Attention to material grievances is a fundamental starting point for any discussion of the incidence of social mobilization, but has causal force only to the extent that grievances are placed in relation to their social construction, and to their translation by collective actors into sets of practices and claims. Here, I have therefore developed a second, related argument, attempting to bring out how the specifically material construction of austerity as an overarching regime is underpinned by a series of associated ideational, institutional, and spatial regimes. These regimes are both pre-conditions for and expressive of the operation of fiscal austerity, and produce a series of enclosures. Social movements mobilize in physical and virtual spaces that are already configured and reconfigured by state power and economic power and social history, and whose multiple configurations both constrain action and provide movements with potent narratives of struggle. Thus the prior existence 
of regimes of civic and ideological austerity are necessary to the development of regimes of fiscal and political austerity; and because fiscal and political austerities in turn re-produce civic and ideological austerities, they also reveal them, make them visible, and enable the productions of social challenge against their material and ideational impacts and premises.

What is, I think, particularly productive about this approach is that it allows us to see more clearly how the practice of austerity is intimately tied to the progressive closure of collective democratic space. Rather, then, than structuring enquiry around economic grievances, it is perhaps more apposite to focus on movement practices, particularly in terms of their capacity to (re)locate relations of power in the physical space of the everyday. The movements of the squares, most clearly, point to the resistant potential of 'spaces of place' in the face of the 'spaces of flow', as Castells (2012) puts it. Against the enmeshing of the public-private at the corporate-institutional level, these movements propose a series of occupational practices, structured around the development of new forms of sociability and solidarity, in order to reveal not just that the 'neo-liberal flow' is characterized by the liquidity of information, technology, and capital, but by the liquidity of democracy.

Faced with this dispersal of power from the realm of lived relations, the occupations of the squares aimed to relocate the democratic within the civic sphere that produced it. This alternative moral economy is also visible in the localized practices of industrial action, beyond the squares, if more marginally so. Perhaps the most conflictual practices to emerge in the wave of mobilizations against the economic crisis - factory occupations, lock-ins, bossnappings, squats, escraches - underscore the multiple resistances of place, with its intimacies and traditions and cultures of material relations over time, to the dispersal of decisional power. Each of these practices makes a claim on the lived space of the social (whether labour or, in the case of escraches, of social relations). By investigating the way that movements develop these practices, attach meanings to them, and forge collective bonds around them, we can also begin to investigate not just the mechanisms of resistance, but their potential for social transformation.

\section{References}

Accornero, G. and P. Ramos Pinto. 2015. 'Mild Mannered'? Protest and Mobilisation in Portugal under Austerity, 2010-2013', West European Politics, 38/3, pp.491-515.

Alesina, A., Barbiero, O., Favero, C., Giavazzi F. and M. Paradisi. 2015. 'Austerity in 2009-13', Economic Policy, 30/83, pp.383-437. 
Amnesty International. 2012. Police Violence in Greece: Not just 'Isolated Incidents'. London: Amnesty International.

Amnesty International. 2013. The State of the World's Human Rights. London: Amnesty International. Asara, V. 2016. 'The Indignados as a Socio-Environmental Movement: Framing the Crisis and Democracy', Environmental Policy and Governance, doi: 10.1002/eet.1721

Bailey, D. J. 2014. 'Contending the Crisis: What Role for Extra-Parliamentary British Politics?', British Politics, 9/1, pp.68-92.

Baldini, M. and T. Poggio. 2014. 'The Italian Housing System and the Global Financial Crisis', Journal of Housing and the Built Environment, 29, pp.317-334.

Baumgarten, B. 2013. 'Geração à Rasca and beyond: Mobilizations in Portugal after 12 March 2011', Current Sociology, 61/4, pp.457-473.

Bernburg, J. G. 2016. Economic Crisis and Mass Protest. The Pots and Pans Revolution in Iceland. London: Routledge.

Bosco, A. and S. Verney. 2012. 'Electoral Epidemic: The Political Cost of Economic Crisis in Southern Europe, 2010-11', South European Society and Politics, 17/2, pp.129-154.

Bosi, L. and L. Zamponi. 2015. 'Direct Social Actions and Economic Crises. The Relationship between Forms of Action and Socio-Economic Context in Italy', PArtecipazione e COnflitto, 8/2, pp.367391.

Cairns, D., de Almeida Alves, N., Alexandre, A. and A. Correia. 2016. Youth Unemployment and Job Precariousness. Political Participation in the Austerity Era. Basingstoke: Palgrave Macmillan.

Cano Fuentes, G., Etxezarreta Etxarri, A., Dol, K. and J. Hoekstra. 2013. 'From Housing Bubble to Repossessions: Spain Compared to Other West European Countries', Housing Studies, 28/8, pp.1197-1217.

Castañeda, E. 2012. 'The Indignados of Spain: A Precedent to Occupy Wall Street', Social Movement Studies, 11/3-4, pp.309-19.

Castells, M. 2012. Networks of Outrage and Hope: Social Movements in the Internet Age. Cambridge: Polity.

Crouch, C. 2004. Post-Democracy. Cambridge: Polity.

Della Porta, D. and A. Mattoni. 2014. 'Patterns of Diffusion and the Transnational Dimension of Protest in the Movements of the Crisis: An Introduction'. In D. della Porta and A. Mattoni (eds), Spreading Protest: Social Movements in Times of Crisis, pp.1-18. Colchester: ECPR Press.

Della Porta, D. 2015. Social Movements in Times of Austerity. Bringing Capitalism back into Social Movement Analysis. Cambridge: Polity. 
Dufresne, A. 2015. 'The Trade Union Response to the European Economic Governance Regime.

Transnational Mobilization and Wage Coordination', Transfer: European Review of Labour and Research, 21/2, pp.141-156.

ETUI. 2016. Strikes in Europe, version 3, July. Brussels: European Trade Union Institute,

https://www.etui.org/Topics/Trade-union-renewal-and-mobilisation/Strikes-in-Europe-version3-July-2016

European Parliament. 2015. The Impact of the Crisis on Fundamental Rights across Member States of the EU. Comparative Analysis. Brussels: Directorate General for Internal Policies, Policy Department C: Citizens' Rights And Constitutional Affairs, http://www.europarl.europa.eu/RegData/etudes/STUD/2015/510021/IPOL_STU(2015)510021_ EN.pdf

Flesher Fominaya, C. 2014a. Social Movements and Globalization. How Protests, Occupations and Uprisings are Changing the World. Basingstoke: Palgrave.

Flesher Fominaya, C. 2014b. 'Put a Gag on it: Spain's Criminalization of 15-M', Red Pepper Magazine, 196, p.19.

Flesher Fominaya, C. 2015a. 'Redefining the Crisis/Redefining Democracy: Mobilising for the Right to Housing in Spain's PAH Movement', South European Society and Politics, 20/4, pp.465-485.

Flesher Fominaya, C. 2015b. 'Debunking Spontaneity: Spain's 15-M/Indignados as Autonomous Movement', Social Movement Studies, 14/2, pp.142-163.

Forno, F., Grasseni, C. and S. Signori. 2015. 'Italy's Solidarity Purchase Groups as "Citizenship Labs" '. In E. Huddart Kennedy, M. J. Cohen and N. T. Krogman (eds), Putting Sustainability into Practice: Applications and Advances in Research on Sustainable Consumption, pp.67-88. Cheltenham: Edward Elgar.

Gall, G. 2011. 'Contemporary Workplace Occupations in Britain', Employee Relations, 33/6, pp.607623.

Gall, G. 2016. 'Injunctions as a Legal Weapon in Collective Industrial Disputes in Britain, 2005-2014', British Journal of Industrial Relations, doi: 10.1111/bjir.12187

Geary, J. 2016. 'Economic Crisis, Austerity and Trade Union Responses: The Irish Case in Comparative Perspective', European Journal of Industrial Relations, 22/2, pp.131-147.

Gerbaudo, P. 2012. Tweets and the Streets: Social Media and Contemporary Activism. London: Pluto. Grittersová, J., Indridason, I. H., Gregory, C. C. and R. Crespo. 2016. 'Austerity and Niche Parties: The Electoral Consequences of Fiscal Reforms', Electoral Studies, 42, pp.276-289.

Guidi, R. and M. Andretta. 2015. 'Between Resistance and Resilience. How Do Italian Solidarity Purchase Groups Change in Times of Crisis and Austerity?', PArtecipazione e COnflitto, 8/2, pp.443-477. 
Hayes, G. 2012. 'Bossnapping: Situating Repertoires of Industrial Action in National and Global Contexts', Modern \& Contemporary France, 20/2, pp.185-201.

Hodkinson, S. 2012. 'The New Urban Enclosures', City, 16/5, pp.500-518.

Hughes, N. 2015. 'The Community Currency Scene in Spain', International Journal of Community Currency Research, 19, pp.1-11.

Hyman, R. 2015. 'Austeritarianism in Europe: What Options for Resistance?'. In D. Natali and B. Vanhercke (eds), Social Policy in the European Union: State of Play 2015, pp.97-126. Brussels: European Trade Union Institute.

Karyotis, G. and W. Rüdig. 2015. 'Blame and Punishment? The Electoral Politics of Extreme Austerity in Greece', Political Studies, 63, pp.2-24.

Keating, M. and D. McCrone. 2013. 'The Crisis of Social Democracy'. In M. Keating and D. McCrone (eds), The Crisis of Social Democracy in Europe, pp.1-13. Edinburgh: Edinburgh UP.

Kern, A., Marien, S. and M. Hooghe. 2015. 'Economic Crisis and Levels of Political Participation in Europe (2002-2010): The Role of Resources and Grievances', West European Politics, 38/3, pp.465-490.

Kickert, W. 2012. 'State Responses to the Fiscal Crisis in Britain, Germany and the Netherlands', Public Management Review, 14/3, pp.299-309.

Kickert, W., Randma-Liiv, T. and R. Savi. 2013. Fiscal Consolidation in Europe: A Comparative Analysis. COCOPS Trend Report, http://www.cocops.eu/wp-content/uploads/2013/10/WP7-trendreport_final.pdf

Kriesi, H. 2012. 'The Political Consequences of the Financial and Economic Crisis in Europe: Electoral Punishment and Popular Protest', Swiss Political Science Review, 18/4, pp.518-522.

Lazzarato M. 2012. The Making of the Indebted Man: An Essay on the Neoliberal Condition. Cambridge, MA: MIT Press.

Lefebvre, H. 1991. The Production of Space. Cambridge: Blackwell.

Martín, I. and I. Urquizu-Sancho. 2012. 'The 2011 General Election in Spain: The Collapse of the Socialist Party', South European Society and Politics, 17/2, pp.347-363.

Mair, P. 2006. 'Ruling the Void? The Hollowing of Western Democracy', New Left Review, 42, pp.2551.

Mayer, M. 2013. 'First World Urban Activism: Beyond Austerity Urbanism and Creative City Politics', City, 17/1, pp.5-19.

Mazzamauro, A. 2014. 'Only One Big Project': Italy's Burgeoning Social Movements', RoarMag, 20 January; https://roarmag.org/essays/italy-movement-housing-income/ 
Meegan, R., Kennett, P., Jones, G. and J. Croft. 2014. 'Global Economic Crisis, Austerity and Neoliberal Urban Governance in England', Cambridge Journal of Regions, Economy and Society, 7/1, pp.137-153.

Monterde, A., Calleja-López, A., Aguilera, M., Barandiaran, X. E. and J. Postill. 2015. 'Multitudinous Identities: A Qualitative and Network Analysis of the 15M Collective Identity', Information, Communication \& Society, 18/8, pp.930-950.

Morris, L. 2016. 'The Moral Economy of Austerity: Analysing UK Welfare Reform', British Journal of Sociology, 67/1, pp.97-117.

Musić, G. 2013. 'Between Facebook and the Picket Line: Street Protests, Labour Strikes and the New Left in the Balkans', Journal of Contemporary Central and Eastern Europe, 21/2-3, pp.321-335.

Nowak, J. and A. Gallas. 2014. 'Mass Strikes against Austerity in Western Europe: A Strategic Assessment', Global Labour Journal, 5, pp.306-321.

O'Brien, T. 2016. 'Mafia', 'Bloodsucking Banks' and 'Red Scum': Understanding the Recent AntiGovernment Mobilisations in Bulgaria', Paper presented at the Europe and the Everyday: Grassroots, EU and the Politics of Crisis Workshop, Aston University, 20 September.

O’Flynn, M., Monaghan, L. F. and M. J. Power. 2014. 'Scapegoating During a Time of Crisis: A Critique of Post-Celtic Tiger Ireland', Sociology, 48/5, pp.921-937.

Peck, J. and A. Tickell. 2002. 'Neoliberalizing Space', Antipode, 34, pp.380-404.

Peterson, A., Wahlström, M. and M. Wennerhag. 2015. 'European Anti-Austerity Protests - Beyond "Old" and "New" Social Movements?', Acta Sociologica, 58/4, pp.293-310.

Pickerill, J. and J. Krinsky. 2012. 'Why Does Occupy Matter?', Social Movement Studies, 11/3-4, pp.279-287.

Pino, M. E. 2013. 'Politics of Indignation: Radical Democracy and Class Struggle beyond Postmodernity', Rethinking Marxism, 25/2, pp.228-241.

Pleyers, G. 2016. '«Nuit Debout»: Citizens are Back in the Squares in Paris', Open Democracy / ISA RC47: Open Movements, 8 April. https://opendemocracy.net/geoffrey-pleyers/nuit-deboutcitizens-are-back-in-squares-in-paris

Quaranta, M. 2016. 'Protesting in 'Hard Times': Evidence from a Comparative Analysis of Europe, 2000-2014', Current Sociology, 64/5, pp.736-756.

Romanos, E. 2014. 'Evictions, Petitions and Escraches: Contentious Housing in Austerity Spain', Social Movement Studies, 13/2, pp.296-302.

Romanos, E. 2016. ' Immigrants as Brokers: Dialogical Diffusion from Spanish indignados to Occupy Wall Street', Social Movement Studies, 15/3, pp.247-262. 
Roos, J. E. and L. Oikonomakis. 2015. 'They Don't Represent Us! The Global Resonance of the Real Democracy Movement from the Indignados to Occupy'. In D. della Porta and A. Mattoni (eds), Spreading Protest: Social Movements in Times of Crisis, pp.117-136. Colchester: ECPR Press

Rüdig, W. and G. Karyotis. 2013. 'Who Protests in Greece? Mass Opposition to Austerity', British Journal of Political Studies, 44, pp.487-513.

Sbicca, J. and R. T. Perdue. 2014. 'Protest Through Presence: Spatial Citizenship and Identity Formation in Contestations of Neoliberal Crises', Social Movement Studies, 13/3, pp.309-327.

Stiglitz, J. E. 2016. The Euro and its Threat to the Future of Europe. London: Allen Lane.

Tejerina, B., Perugorría, I., Benski, T. and L. Langman. 2013. 'From Indignation to Occupation: A New Wave of Global Mobilization', Current Sociology, 61, pp.377-392.

Tonkiss, F. 2013. 'Austerity Urbanism and the Makeshift City', City, 17/3, pp.312-324.

Tsatsanis, E., Freire A. and Y. Tsirbas. 2014. 'The Impact of the Economic Crisis on the Ideological Space in Portugal and Greece: A Comparison of Elites and Voters', South European Society and Politics, 19/4, pp.519-540.

United Nations Human Rights Council. 2013. Report of the Special Rapporteur on the Rights to Freedom of Peaceful Assembly and of Association, Maina Kiai. Mission to the United Kingdom of Great Britain and Northern Ireland. Geneva: UNHRC.

Varga, M. 2015. 'Trade Unions and Austerity in Central and Eastern Europe: Did they do Something about it?', Transfer: European Review of Labour and Research, 21/3, pp.313-326.

Vicente, L. and P. Goicoechea. 2015. 'Gagged in the Name of Security', OpenDemocracy, 12 May, https://www.opendemocracy.net/can-europe-make-it/lydia-vicente-patriciagoicoechea/gagged-in-name-of-security

Yates, L. 2015. 'Rethinking Prefiguration: Alternatives, Micropolitics and Goals in Social Movements', Social Movement Studies, 14/1, pp.1-21.

\footnotetext{
1 'Public sector strike rallies held across the UK', BBC News, 1 December 2011, http://www.bbc.co.uk/news/uk-15953806

2 The EU's Excessive Deficit Procedure places states' fiscal policies under the monitoring of the European Commission. The UK entered in 2008; Spain, Greece, Ireland, France, Germany, Italy, Portugal, the Netherlands, Belgium, and Austria entered in 2009; Denmark entered in 2010.

${ }^{3}$ In Ireland, at the March 2011 general election the free market conservative Fine Gael replaced the more centrist Fianna Fáil as the dominant governing party, but did so in coalition with the centre-left Labour party.

${ }^{4}$ For leisure centres, see protests against plans announced in 2013 by Manchester and Birmingham city councils to achieve local budget cuts by closing five and nine leisure centres and swimming pools respectively, replacing them with a smaller number of privately run leisure centres: 'Protest over Manchester swimming pool closure plans', BBC News, 2 February 2013,
} 
http://www.bbc.co.uk/news/uk-england-manchester-21306818; 'Nine Birmingham leisure centres face closure through council cuts', BBC News, 26 November 2013, http://www.bbc.co.uk/news/ukengland-birmingham-25105623. For Barnet, see 'Squatters reopen Friern Barnet library after council closes service', The Guardian, 11 September 2012,

https://www.theguardian.com/books/2012/sep/11/squatters-reopen-friern-barnet-library. A BBC investigation, based on Freedom of Information requests, found that between 2010 and March 2016 the number of council-run libraries in the UK fell from 4290 to 3765 . During this period, local councils closed 343 libraries, and transferred a further 232 out of local authority control (174 to community groups, and 58 outsourced to private concerns). At the same time, the number of paid library staff positions was reduced by approximately $25 \%$, as paid staff were replaced by unpaid volunteers. See 'Libraries lose a quarter of staff as hundreds close', BBC News, 29 March 2016, http://www.bbc.co.uk/news/uk-england-35707956

${ }^{5}$ See ' "Two legal reform projects undermine the rights of assembly and expression in Spain" - UN experts', UN Human Rights Council press release, 23 February 2015, http://www.ohchr.org/EN/NewsEvents/Pages/DisplayNews.aspx?NewsID=15597\&LangID=E ${ }^{6}$ Amanda Brown, speech to the ILO Conference 2016, 'TUC speaks out against the Trade Union Act', 6 June; see https://www.tuc.org.uk/CAS-TUC 